\title{
LEAPFROGGING TO RENEWABLE ENERGY: THE OPPORTUNITY FOR UNMET ELECTRICITY MARKETS
}

\author{
B. Batinge ${ }^{1 *}$, J.K. Musango ${ }^{1}$ \& A.C. Brent ${ }^{2,3}$
}

\section{ARTICLE INFO}

\section{Article details}

Submitted by authors

Accepted for publication 20 Sep 2017

Available online

Contact details

Corresponding author

benjaminb50@gmail.com

Author affiliations

1 School of Public Leadership, Urban Modelling and Metabolism Assessment (uMAMA), Centre for Complex Systems in Transition (CST), Stellenbosch University, South Africa

2 Department of Industrial Engineering, Centre for Renewable and Sustainable Energy Studies (CRSES), Urban Modelling and Metabolism Assessment (UMAMA), Stellenbosch University, South Africa

3 Sustainable Energy Systems, Engineering and Computer Science, Victoria University of Wellington, New Zealand

DOI

http://dx.doi.org/10.7166/28-4-1702
Electricity plays a crucial role in the socio-economic development of any country. Developing countries, however, unlike their developed counterparts, do not have electricity markets that are fully satisfied, nor are they 'laden' with large-scale infrastructure that could create inertia about making the transition. The objective of this paper is to identify the potential trajectories for unmet electricity markets in sub-Saharan Africa to leapfrog to renewable energy as they strive to accelerate access to electricity. The following key drivers of renewable energy leapfrogging in unmet electricity markets were identified from the review: the need to achieve sustainability targets; the availability of renewable energy resources on a sufficient scale; growing investment in renewable energy; maturing niche renewable technologies; a weakening renewable energy cost hypothesis; and a growing population and increasing urbanisation. The paper further conceptualised three potential transition paradigms: revolutionary, scattered, and coned pathways. These paradigms were defined by the pace and magnitude of the transition that can be observed, and depend on the intensity of the identified drivers in a specific unmet electricity market. The paper argues that the largely unmet electricity market in sub-Saharan Africa provides an opportunity to leapfrog the fossilintensive energy regime to adopt a renewable energy regime.

\section{OPSOMMING}

Elektrisiteit speel 'n belangrike rol in die sosio-ekonomiese ontwikkeling van enige land. In teenstelling met hul ontwikkelde eweknieë, is ontwikkelende lande se elektrisiteitsmarkte nog nie versadig nie, en is hulle ook boonop nie opgesaal met grootskaalse infrastruktuur wat oorgang sou vertraag nie. Die doel van hierdie artikel is om die potensiële trajekte vir onontginde elektrisiteitsmarkte in sub-Sahara-Afrika te identifiseer om oor te skakel na hernubare energie in hul strewe daarna om toegang tot elektrisiteit te versnel. Die behoefte om volhoubaarheidsdoelwitte te bereik word ondersoek, asook die beskikbaarheid van hernubare energiebronne op voldoende skaal; toenemende belegging in hernubare energie; die ontwikkeling van nie-hernubare tegnologie; die hipotese rakende die verminderde koste verbonde aan hernubare energie-infrakstruktuur; en die bevolkingsaanwas en verstedeliking. Die artikel stel ook 3 omskakeling-paradigmas voor: revolusionêre, verspreide of gefokusde roetes. Dit was gedefinieer deur die tempo en omvang van die omskakeling waargeneem, en hang af van die intensiteit van die geïdentifiseerde drywers in die mark. Die argument word gemaak dat die onbevredigde elektrisiteitsmark in die sub-Sahara mark geleenthede bied om die fosielbrandstof-intensiewe energie-opwekking verby te steek en sodoende ' $n$ hernubare energie regime in werking te stel. 
The global society is increasingly energy-reliant, resulting in fast-paced energy demands, especially in the form of electricity. Electricity is essential for providing most daily energy services, such as: cooking, heating, lighting, and cooling, and for powering electric devices. Despite its crucial role, about 1.2 billion people, located mainly in sub-Saharan Africa, still lack access to electricity [41]. Since 2000, the number of people in sub-Saharan Africa without access to electricity has increased by about 200 million [37] due, among other things, to a growing population and rapid urbanisation. This has resulted in the sub-region being the most electricity-deprived area in the world. In recognition of the intensifying energy problem, the United Nations set universal access to modern energy by 2030 as one of the sustainable development goals (SDGs) [79]. Energy has therefore become a topical subject in recent discourse, appearing in the spotlight of both academic and nonacademic research, given the varied services provided through electricity [1, 20, 44, 56, 61, 63].

As part of the effort to expand and decentralise electricity access, a growing body of research on energy transition $[24,27,31,43,68]$ has emerged. A transition to renewable energy in particular is gaining momentum as a conduit to universal energy access for all. Furthermore, leapfrogging to renewable energy is considered a potential route to achieving energy security $[8,14,16,30,60,72$, 84]. In light of the long-term benefits of generating electricity from renewable sources, some developed countries are effectively harnessing their renewable energy resources for electricity services. As an illustration, about 95 per cent of Norway's electricity is generated through hydropower [26]; Denmark is one of the leading countries with wind-generated power [59]; and Germany has significantly increased its solar power [59], notwithstanding the country's limited solar resources. This is, however, not the case in developing countries, especially in sub-Saharan Africa, where the potential of renewable energy resources such as solar, hydro, wind, geothermal, and biomass, is high.

Different factors drive energy transitions; these include, inter alia, environmental protection, energy security, and health hazards. However, when it comes to a renewable energy transition, contextual limitations and opportunities play a key role, as established by Batinge, Musango and Alan [12]. For instance, the transition that occurred in Germany, following the decommissioning of nuclear plants and the growth in solar Photovoltaic (PV) from less than one gigawatt (GW) to twentyfour GW between 2004 and 2014 [50], is not comparable to a transition to renewable energy for electricity production in sub-Saharan Africa. Prior to the nuclear decommissioning and introduction of solar PV, Germany already had a 100 per cent electricity access rate. It therefore took almost a decade to expand the country's solar capacity, given the low sense of urgency. Similarly, other countries that are leading in renewable energy technology developments, such as Denmark, the Netherlands, Italy, Japan, and the United States, have 100 per cent electricity access rates. Their transition motives differ from those of sub-Saharan Africa, where more than half the population do not have access to electricity [61].

Developing countries, unlike their developed counterparts, do not have fully satisfied electricity markets, nor are they 'laden' with large-scale infrastructure that could create inertia about making the transition. There is, therefore, a greater sense of urgency to build electricity infrastructure in developing countries. These contextual differences make the potential of renewable energy leapfrogging in sub-Saharan Africa more compelling. The objective of this paper was, therefore, to identify potential drivers and trajectories of leapfrogging in unmet electricity markets. This was achieved through a literature review and content analysis. The paper argues that leapfrogging in renewable energy is an opportunity to accelerate electricity access in unmet markets, particularly in sub-Saharan Africa.

The rest of the paper is organised as follows. First, an overview of sub-Saharan Africa as an unmet electricity market is presented. This section emphasises the limited nature of electricity access in the region. The next section discusses the concept of leapfrogging as a form of transition, followed by the different types of leapfrogging. The potential for leapfrogging to renewable energy in unmet electricity markets is then assessed, highlighting the key drivers of leapfrogging. The ensuing section presents reconceptualised leapfrogging paradigms, and discusses the potential pathways of leapfrogging to renewable energy. Finally, conclusions drawn from insights into leapfrogging in unmet electricity markets and opportunities for rapid electricity access in Africa are presented. 
In Africa, especially in the sub-Saharan region, lack of access to energy is an endemic problem, causing firms and households to resort to their own methods of meeting their energy needs for basic services. About six per cent of power generation capacity in sub-Saharan Africa originates from own generation, while in lower-income countries, and the western part of the continent, this number is almost double [69]. This is irrespective of the fact that such self-generated power costs more than the supply from national/public power systems [69]. Steinbuks and Foster [69] conclude that the drive for a firm to own a power generation plant stems from the unreliability of the national power system, the size of the firm, the sector of industry within which it operates, and its tendency to export. Own power generation, however, especially through fossil fuels, is unsustainable as a longterm substitute, as it increases overheads and undermines return on investment.

Energy access describes an individual, household, or entity's initial supply connection that then rises gradually to that of a regional average [39]. The UN Secretary General's Advisory Group on Energy and Climate Change [6] defines energy access as "a basic minimum threshold of modern energy services for both consumption and productive uses. Access to these modern energy services must be reliable and affordable, sustainable and, where feasible, from low greenhouse gas emitting energy sources". The Asian Development Bank [3] observes that energy access includes making electricity available to households, improved supply and delivery of energy services, modern fuels and/or heating, and finance in order to access energy.

There is no standard definition of an 'unmet electricity market'. This paper offers a definition, taking into account the characteristics of modern energy access: a basic minimum threshold, affordable, reliable, sustainable, and environment-friendly. Following these features, a definition of an unmet electricity market is derived from the United Nations' Advisory Group on Energy and Climate Change [6], which defines a lack of energy access as people not having access to any, or the basic minimum threshold, of affordable, reliable, sustainable, and environment-friendly modern energy services for consumption and production activities. 'Unmet power/electricity market' in this paper refers to the number or proportion of household, commercial, and industrial electricity demands that remain unsatisfied - that is, with no access to electricity at all. It also includes those that are connected to some form of grid, but that do not have a reliable supply. 'Reliability' in this context refers to a consistent and uninterrupted supply of electricity for at least five out of seven days in a week. This definition is important, in order to include households that might be connected to a grid of some sort but that do not get power ('grid connection' does not equal 'electricity access'), since power outages are a relatively frequent occurrence in sub-Saharan Africa [61].

The extent of Africa's electricity deficit is demonstrated in Figure 1, where the highlighted depth of colour on the map, from purple to red, reveals the intensity of energy inadequacy, while the yellow bubble depicts the size of the population in millions across the continent. Ghana, for example, remains one of the sub-Saharan countries where a significant number of people are still not connected to national, regional, or local electricity grids. Data from IEA [36] highlights subSaharan Africa's low electricity access, with countries such as Chad, Malawi, Burundi, the Central African Republic, the Democratic Republic of Congo, and Sierra Leone recording less than 10 per cent of the entire population having access to electricity.

The UN's Sustainable Energy for All (SE4ALL) goal of ensuring universal access to energy by 2030 [62] would be unrealisable, should the current trend of investment persist. It is estimated that some 600 million people in Africa alone would still have no access to electricity by 2030, if the current business-as-usual scenario continues [61]. It is clearly relevant that Eberhard, Foster, BriceñoGarmendia, Ouedraogo, Camos, \& Shkaratan [21] noted less than a decade ago that sub-Saharan Africa is in a power crisis. The electricity problem in sub-Saharan Africa is evident from the fact that many households are not connected to the national power grid, and neither do they have access to offgrid power. The inefficiencies in Africa's electricity system are also evident even among people connected to the grid; they still experience rampant power outages [61]. The economic implication of this unreliable electricity supply is estimated to account for a two per cent decline in Gross Domestic Product (GDP) [61], and by two to four per cent as productivity and output levels fall, according to the Africa-Progress-Panel [5]. This is consistent with the earlier conclusions of Andersen and Dalgaard [9], who state that a single percentage increase in power outages causes GDP per capita to decline by 2.86 per cent in the long run. 

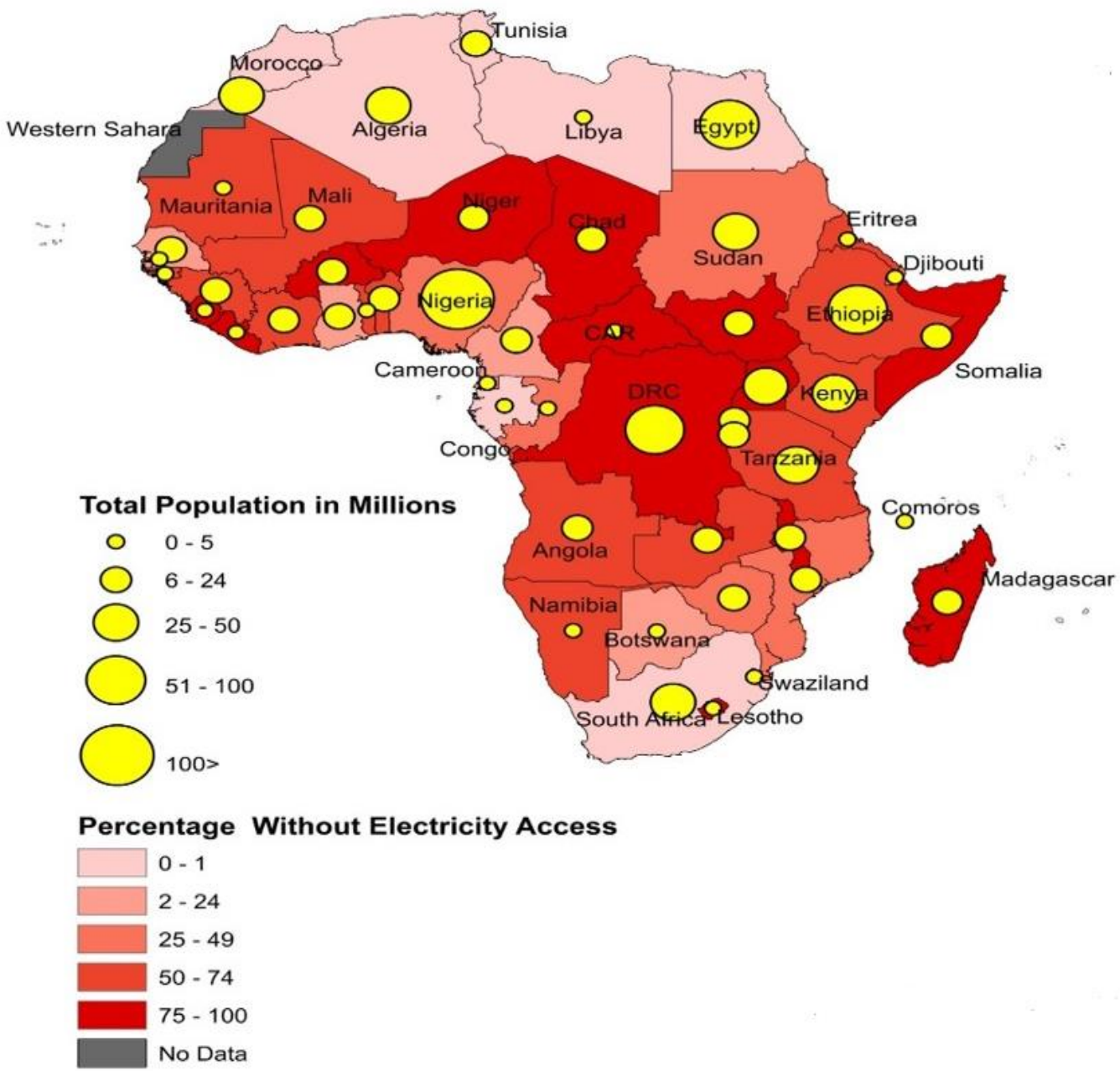

Figure 1: Electricity access in Africa, 2012 (Data source: IEA [38])

The on-going electricity problem in sub-Saharan Africa appears immune to the mediations implemented so far. This persistent undersupply of electricity is largely attributable to the limited financial resources allocated to the sector. Indeed, energy is a capital-intensive investment [66]. Castellano, Kendall, Nikomarov and Swemmer [19] estimate that USD 835 billion would be required to ensure electricity access to all. In another study, the IEA and World Bank (2014) postulate that a total investment of USD 890 billion is needed to attain universal electrification between 2011 and 2030, without factoring in the financial requirements for the operation and maintenance of the existing electricity systems. It is clear that the current annual investment of USD 8 billion in electricity across sub-Saharan Africa is clearly inadequate to support the power generation required to address the growing electricity demand [61]. An annual investment of USD 45 billion would be needed to ensure universal access to modern energy by 2030 [39], and USD 46 billion by 2040 [37].

Szabó, Bódis, Huld and Moner-Girona [18] observe that a conventional large-scale centralised power infrastructure with grid extension system has been unsuccessful in sub-Saharan Africa. Reliance on grid extension alone would not be sufficient to attain the universal electrification target by 2030 [13]. The scale and infrastructural requirements of a conventional energy system involve a long installation time, and stretch the limited financial capacity of developing countries. In areas where the system is installed, challenges such as an inadequate transmission capacity and frequent breaks in transmission result in a significant difference between a plant's installed capacity and its productivity. The idea of investing in distributed off-grid electricity systems in sub-Saharan Africa is thus important for two main reasons. Firstly, there is excessive stress on the national transmission lines that carry power for distribution over long distances. Secondly, the continent is characterised by countries with sparsely populated rural settlements; this makes distributed power generation 
more efficient than a centralised generation system [72]. In Africa, fossil energy constitutes a large proportion of the electricity systems, even though there are vast renewable energy opportunities. According to Scott [61], 85 per cent of Africa's electricity was generated through fossil fuels in 2012 . In sub-Saharan Africa, in a 'business as usual' scenario it is projected that 81 gigawatts (GW) of power will be added by 2040, mainly from fossil fuels [61]. The goal of universal access to modern energy in Africa thus appears to be challenging.

\section{LEAPFROGGING AS A FORM OF TRANSITION}

Leapfrogging is gaining popularity in the transition discourse, and is commonly promoted in the sustainable energy arena. The concept of leapfrogging is not novel in the academic literature [25, $29,46,52,58,72]$. It emerged as the rate of inventing new technologies increased, and the potential to transition from one product or service to another became greater. As a result, the possibility emerges for some consumers to skip a 'generation' of technologies (products or services) entirely to adopt novel and modern ones [29]. Leapfrogging is generally defined as a development strategy in which industrialising nations skip conventional economic growth stages by adopting contemporary resource-efficient technologies in order to reduce post-consumption repercussions, such as pollution [58]. Leapfrogging, according to Lee and Lim [46], is a form of catching-up with contemporary technology. Hobday [33] refers to leapfrogging as a situation where users of a vintage form of a technology skip the current dominant form of that technology - with its excessive investment requirements - and go directly to its modern form. A common example of leapfrogging technology is telecommunication devices. Most developing countries leapfrogged to mobile telephones without completely adopting the landline telephone system, which was the dominant form of virtual communication [51].

There are different opinions on the capacity of countries to leapfrog regime technologies. In international leapfrogging, for example, Tukker [74] and Gallagher [25] surmise that new adopters, such as developing countries, often rely on their developed counterparts for new energy solutions until domestic capabilities become adequate to produce and integrate advanced energy technologies. Gallagher [25] further argues that, due to the limited technological capabilities for complex innovations in large-scale socio-technical systems, energy technology leapfrogging in developing countries is made more difficult by policy inconsistency, the unwillingness of developed countries to transition, and limited domestic capabilities. Contrary to the observation of Gallagher [25], Lee and Lim [46] posit that late adopters of a technology do not simply follow the path of technological development of pioneers, but might entirely skip some stages of an emerging technology and create paths to improve it. Developing countries, by nature of their small-sized infrastructure, can easily adopt new or emerging technologies that are more advanced, thus avoiding the resource-intensive path of conventional energy development experienced by developed countries [29].

The success of energy technology leapfrogging could originate from the global interest in reducing emissions and growing pressure from socio-technical landscape entities [40,78]. The pursuit of renewable energy quotas in the total energy mix, as part of the Sustainable Development Goals [34], could potentially drive successful leapfrogging in energy technology. Every economy can be regarded as a beginner in the emerging techno-economic paradigm, and so has the potential to leapfrog [57]. The national, regional, and sectorial innovation systems support this observation [18].

\subsection{Types of leapfrogging}

Lee and Lim [46] identify three forms of leapfrogging (LF): path-skipping, path-creating, and pathfollowing. Gallagher [25] considers only the first two forms to be leapfrogging, and regards pathfollowing as a gradual form of transitioning. Given that rapid transition and skipping stages of conventional practice or technology are key characteristics in the definition of leapfrogging, this paper holds a similar view to that of Lee and Lim [46] about the three forms of leapfrogging. Following conventional pathways may be brief, and adopting new technology in short timeframes qualifies as a form of leapfrogging. Each of the three forms of leapfrogging is shown in Error! Reference source not found., and each is further elaborated on in the sub-sections that follow. 


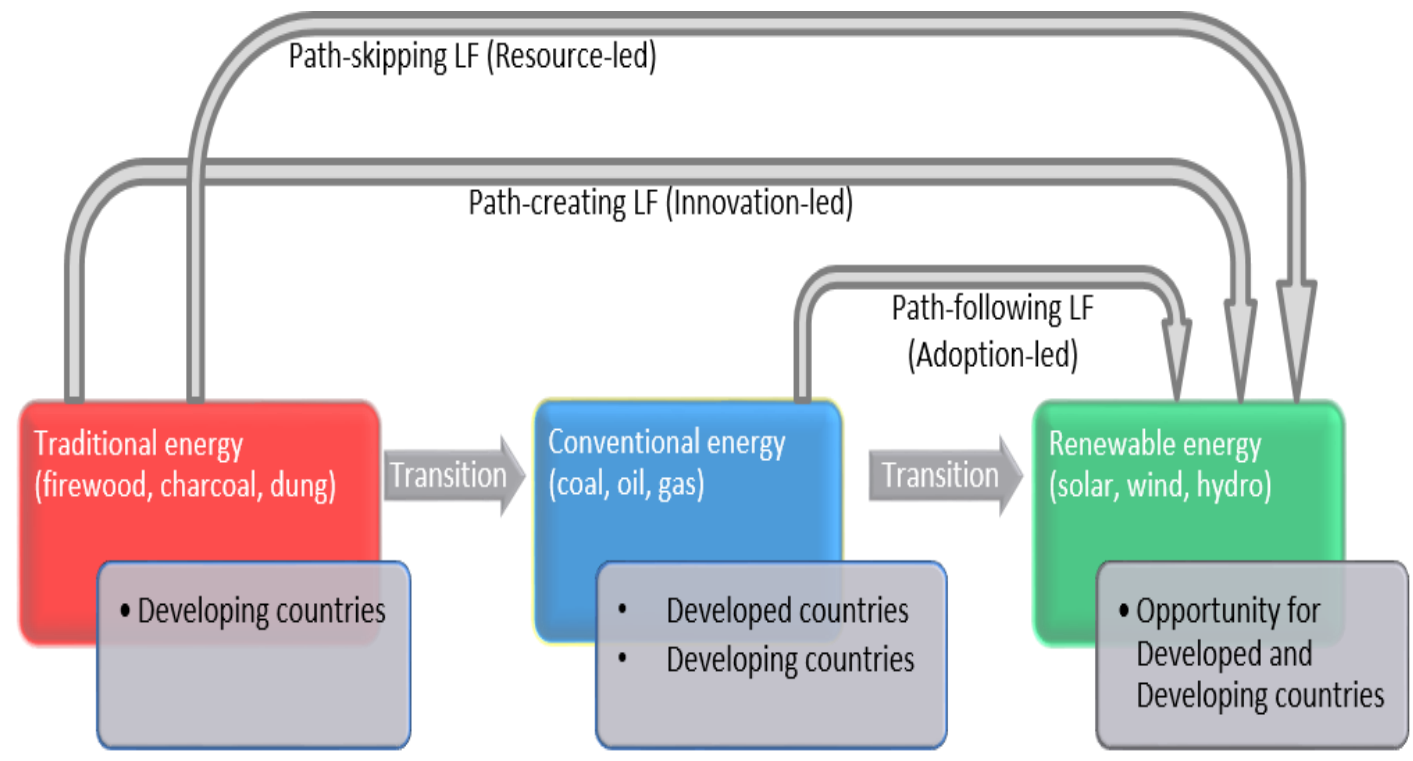

Figure 2: Types of leapfrogging (LF) (Source: Authors)

\subsubsection{Path-skipping}

Path-skipping is the same as Gallagher's [25] description of leapfrogging: skipping over generations of technology. An example given earlier is the adoption of mobile phones (wireless) in Africa, without first going through the conventional landline (wired) regime. In the energy sector, this type of leapfrogging involves jumping to renewable energy without experiencing the dominant energy source regime (fossil fuel), and jumping from the dominant mode of delivering electricity (centralised grid transmission and distribution) to decentralised electricity provision through minigrids and stand-alone systems. Since sub-Saharan Africa has low electricity access rates and a large unmet electricity market, introducing renewable energy technologies (such as solar PV, wind, and hydro) that result in skipping conventional fossil fuels for the provision of electricity would constitute technological leapfrogging. This is described by Lee and Lim [46] as path-skipping and by Gallagher [25] as skipping over generations of (fossil fuel) technology. Path-skipping leapfrogging can be perceived as a resource-led leapfrogging; a country that is endowed with the resources for modern technology can easily skip conventional technology on the basis of the advantage of such resource accessibility.

\subsubsection{Path-creating}

Path-creating as a form of leapfrogging implies that late adopters explore their own path of technology development by creating a new path, after following the path of the initial adopters [46]. This type of leapfrogging is characterised by skipping over a generation of technologies and consequently leading in the production, adoption, or use of such technology [25]. An example is the emergence of the Korean steel industry, which leapfrogged and overtook leading steel producers to become the industry leader [25]. In the energy sector, this leapfrogging would include advancing to become the leader in renewable energy technology. For instance, if Africa commits to, and succeeds in, fulfilling universal energy access by providing the excess market demand with renewable energy, the continent would become the leader in renewable energy access by share of total demand. This would fulfil Gallagher's [25] second definition of leapfrogging. Path-creating is the situation where a nation's ability to innovate quickly and more efficiently can propel it to become a market leader in a given technology.

\subsubsection{Path-following}

Path-following is a traditional form of change: late adopters of a technology follow the same path as the forerunners, but in a shorter time [46]. This is usually because the adopter's technology is out-dated; hence the need to transition to a 'new conventional' technology. The fact that late adopters briefly use the technology before the next conventional technology is available means that their transition is regarded as a traditional or weak form of leapfrogging. Path-following is a weak form of innovation because the nation may not necessarily champion innovation or lead in resource endowment; the nation may leapfrog to the latest technology for reasons such as diffusion, and therefore use the technology for a shorter time before transitioning. 


\subsection{Differentiating leapfrogging from technical change}

Leapfrogging is not the same as technical change, even if the outcome is similar. Not every sustainable clean energy transition is regarded as leapfrogging. Encouraging the use of sustainably clean technologies that do not require a generation of conventional technologies to be skipped is therefore not considered leapfrogging [25]. A government policy to encourage consumers to choose the most efficient, available, or affordable fuel alternative among existing conventional fuel types is a form of technical change; it is not leapfrogging. For example, petroleum and natural gas are both contemporary fossil fuel types. If a national policy results in a migration from one to the other, it is considered a transition or technical change, because both are conventional energies, and there is no leap between generations of regime technologies.

National policy, however, can be an impetus for leapfrogging. Brazil is an example: the state stimulated the adoption of ethanol-fuelled vehicles by introducing disincentives for conventional gasoline-fuelled vehicles. This is considered leapfrogging because ethanol-fuelled vehicles were a new and emerging technology introduced into a market dominated by conventional gasoline-fuelled automobiles [29]. Leapfrogging can also differ in country and industry contexts [46]. For example, while Goldemberg [29] considers the ethanol-fuelled vehicles in Brazil as a form of leapfrogging, Gallagher [25] questions the effectiveness of ethanol-fuelled automobile adoption in China.

\section{POTENTIAL OF LEAPFROGGING TO RENEWABLE ENERGY IN UNMET ELECTRICITY MARKETS}

Universal access to modern energy in Africa is not an easy goal, considering current trends. The demand for energy services in the form of electricity for household and commercial purposes has never been resolved across the continent $[11,35,39]$. Studies forecasting electricity access for the next two decades suggest that the current trend of development in electricity systems would not lead to sustainable electricity access $[39,61]$. Even though the total installed power capacity is expected to increase significantly, especially in developing countries, the population growth in these areas would offset the additional capacity and create even more insecurity in energy services.

Notwithstanding the present gloomy electricity environment in sub-Saharan Africa, there are opportunities for a brighter and more self-sufficient power future. Renewable energy innovation is growing fast, offering energy alternatives to developing countries that would allow them to increase electricity access rapidly. The key driving factors of leapfrogging conventional energy to renewable energy for electricity generation in the unmet electricity market include: the global goals of a sustainable energy future and universal electricity access; the abundance of renewable energy resources, especially in sub-Saharan Africa; the financial commitment to invest in renewable energy; the growing renewable energy technology; the declining cost of renewables; and rapid urbanisation and population growth. These drivers are depicted in Error! Reference source not found..

These driving factors are essential, and boost the potential for leapfrogging to occur in an unmet electricity market context. In no way do they represent an exhaustive list of potential drivers for such a transition. When further categorising unmet electricity markets into sub-units and niches, only some of the drivers mentioned above might be identified. Although these factors would potentially become an impetus for leapfrogging in unmet electricity markets, they are not unknown in satisfied markets. Driving factors such as climate change and innovation, for example, can most likely be found in fully satisfied markets too. However, excess demand and renewable energy resources are very common drivers in unmet electricity markets in sub-Saharan Africa. 


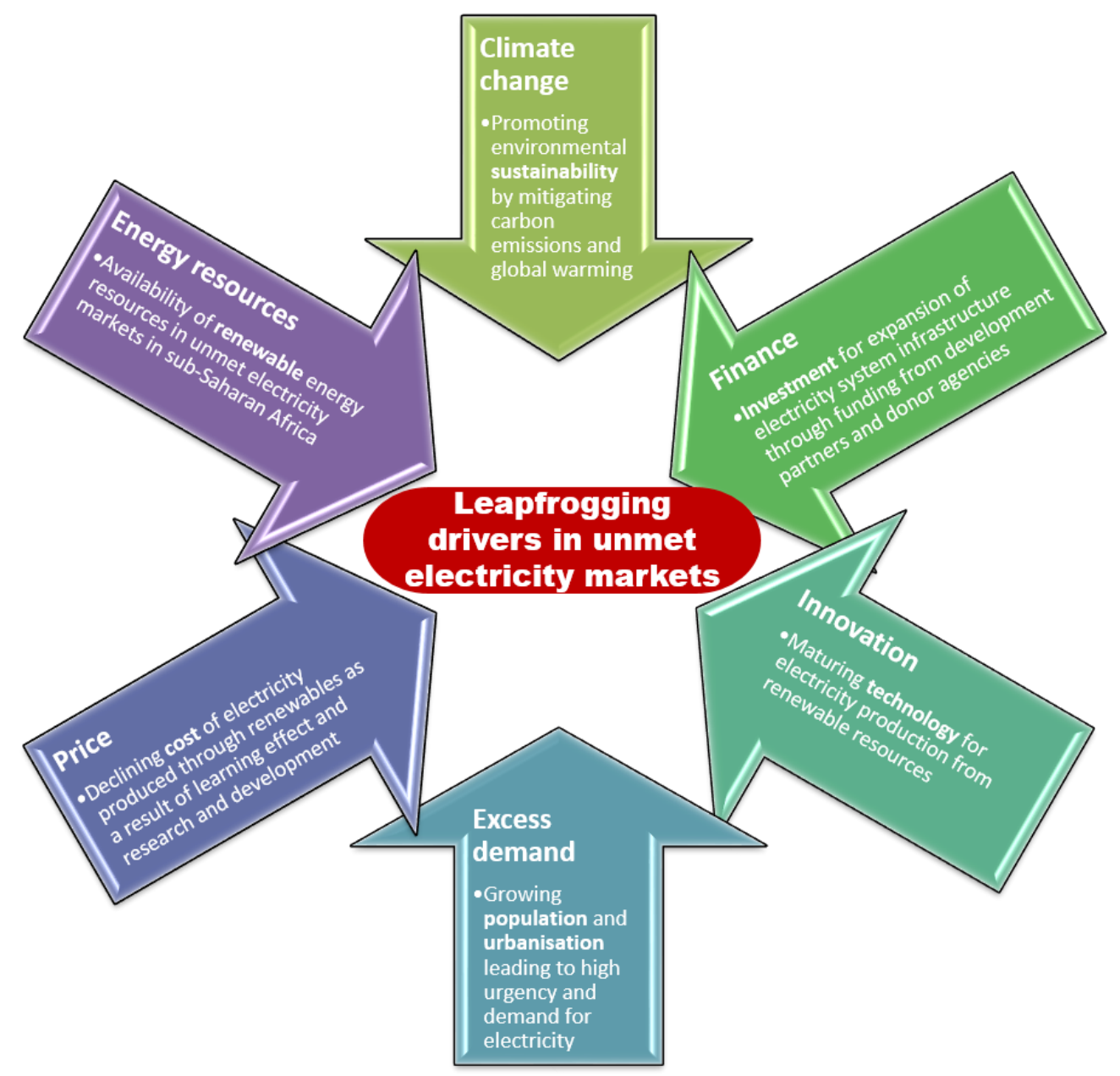

Figure 3: Leapfrogging drivers in unmet electricity markets (Source: Authors)

\subsection{Sustainable energy goals and targets}

The transition from traditional biomass to coal, and eventually to oil, propelled the industrial revolution, which saw many presently developed countries placed on the road to rapid growth and innovation. But the transition accelerated in the mid-twentieth century. The industrial revolution had created a competitive global market of national traders whose major trade commodity was determined by comparative and absolute cost advantages. The transition to renewable energy in the twenty-first century, however, seems to be pursued as a global co-operative objective where sustainable energy initiatives are extensively promoted at the international level. This is evident in United Nations treaties, such as the Framework Convention on Climate Change [75], the Kyoto Protocol [76], the Copenhagen Accord (2009), the Cancun Agreement [77] and, most recently, the Paris Agreement [78]. The active role of the international community in championing a globally sustainable energy environment can be attributed, among other things, to the burgeoning benefits of renewable energy and the adverse consequences (to human health, for example) of fossil fuels. An estimated 4.3 million people died from exposure to polluted air in household environments in 2012, with most of this number recorded in developing/low income countries [54]. The presence of international organisations such as the United Nations and the World Bank, and the extensive national bodies and initiatives advocating for a transition to sustainable energy, is a major incentive for developing countries to leapfrog to renewable energy. The broad stakeholder spectrum in the global sustainability agenda has motivated many countries, including those in sub-Saharan Africa, to set renewable energy targets in their overall energy development plans. This is a clear sign that, despite the limitations that may hinder the competitiveness of renewable energy, a growing opportunity for leapfrogging is apparent and driven by the goal of sustainability. 


\subsection{Available renewable energy resources and scale efficiency}

Besides the technological and innovative constraints of the renewable energy transition emphasised in the literature [64], there is also the issue of the limited availability of renewable energy resources and the unpredictability of weather conditions [64]. However, the viability of the argument about weather predictability is being constantly reduced by rapid advances in technology that is capable of adjusting to weather variations, and other complex tasks, such as tracking sun rays in the case of solar technology. There is also only limited variation in seasonality across the subcontinent, and hence fewer seasonal challenges for renewable energy. The continent, because of its geographical position, records sunshine on most days, averaging 325 days a year [45]. Compared with most parts of the global north, the region thus favours the use of renewable energy, especially in electricity production, with abundant resources and opportunities in solar, wind, hydro, biomass, and geothermal energy [10]. According to Asami and Nawfal [10], while the total installed power capacity in 2014 was $150 \mathrm{GW}$, the potential of solar PV and wind on the continent was 300,000 GW and $250,000 \mathrm{GW}$ respectively - clear evidence of resource abundance.

Renewable energy technology is also scale efficient, even when installed in smaller units. New technology that offers higher economies of scale reduces leapfrogging tendencies [49]. Mature networks, which are common in developed countries, constrain the potential for leapfrogging due to the inertia created by the investment [49] sunk into conventional infrastructure. Strangely, Mody and Sherman [49] also found that leapfrogging to electronic technologies was absent in countries with low network maturity. They concluded that the scale of investment required to leapfrog is far greater than the capabilities of developing countries. The findings of Mody and Sherman [49] do not, however, negate the argument about the leapfrogging potential in developing countries, for the following reasons: the type of technology they studied (the telephone) differs from other technologies (such as energy) in both scale and functionality, and the context (in time and location) is different. The contention that there is a higher leapfrogging potential in developing countries is evident in the penetration of mobile money services - a mobile phone-based financial service without a bank account. In 2015, sub-Saharan Africa accounted for 52 per cent of active mobile money services globally [32]. Unlike the fossil energy alternatives, whose return on investment increases with economies of scale, maximising investment returns on renewable energy is not heavily dependent on economies of scale. Wind, solar, and mini-hydro opportunities scattered across Africa therefore increase the chances of leapfrogging to renewable energy in the region, since installing them in smaller units does not sufficiently diminish their returns, compared with fossil alternatives.

\subsection{Growing investment in renewable energy}

As part of the initiatives to alleviate energy poverty in Africa, some regional blocs within sub-Saharan Africa are promoting regional integration through energy trading to expand electricity generation. The initiatives, which constitute regional blocs of power markets, include the Southern Africa Power Pool (SAPP); the Eastern Africa Power Pool (EAPP); the Central Africa Power Pool (CAPP); and the Western Africa Power Pool (WAPP) [28]. Governmental development agencies from developed countries, as well as other international bodies, are investing in the sub-Saharan African energy sector, and significant donations are specifically earmarked for renewable energy expansion in the region. Some of these financial initiatives are listed in Error! Not a valid bookmark self-reference..

Other funding initiatives for clean and sustainable energy access in Africa include the EU-Africa Infrastructure Trust Fund (ITF), Energy, Eco-development and Resilience in Africa (EERA), the African Energy Leaders Group (AELG), the African Renewable Energy Alliance (AREA), and Lighting Africa. These projects create multi-stakeholder platforms for information exchange on policies, regulatory frameworks, and financial tools to facilitate renewable energy technology development, adoption, and expansion in Africa. 
Table 1: Funding initiatives alleviating renewable energy investment challenges (Sources: Mendoza [48]; REN21 [59])

\begin{tabular}{|c|c|}
\hline Project & Goal and description \\
\hline $\begin{array}{l}\text { Power Africa } \\
\text { Initiative - Electrify } \\
\text { Africa Act, } 2015 \text { - } \\
\text { United States } \\
\text { Government }\end{array}$ & $\begin{array}{l}\text { The project's goal is to improve access to affordable and reliable electricity in sub- } \\
\text { Saharan Africa. It also aims to provide power services for } 50 \text { million rural and urban } \\
\text { dwellers by } 2020 \text { through the installation of } 30,000 \text { megawatts of clean energy } \\
\text { generation. }\end{array}$ \\
\hline $\begin{array}{l}\text { Energy Africa } \\
\text { Campaign (United } \\
\text { Kingdom's } \\
\text { Department for } \\
\text { International } \\
\text { Development) }\end{array}$ & $\begin{array}{l}\text { The campaign started in } 2015 \text {, and is centred on energy access for rural } \\
\text { communities that are not connected to the national grid by investing in off-grid } \\
\text { energy firms, overcoming regulatory barriers, fostering innovation, and speedy } \\
\text { delivery of solar energy systems to promote universal access to energy by } 2030 \text {. }\end{array}$ \\
\hline $\begin{array}{l}\text { New Deal for Energy } \\
\text { in Africa - African } \\
\text { Development Bank }\end{array}$ & $\begin{array}{l}\text { A decade-long project launched in } 2015 \text { to promote universal access to energy in } \\
\text { Africa by } 2025 \text {. It also engages in providing technical assistance for energy utility } \\
\text { restructuring, de-risking, and making funds accessible for energy projects, boosting } \\
\text { regional interconnections, and advising on efficient energy sector regulation. }\end{array}$ \\
\hline $\begin{array}{l}\text { Electrification } \\
\text { Financing Initiative - } \\
\text { EU }\end{array}$ & $\begin{array}{l}\text { This project was launched in } 2016 \text { to boost off-grid energy access for rural sub- } \\
\text { Saharan African communities. It serves as a financing conduit for market } \\
\text { development and private sector initiatives to promote sustainable energy solutions } \\
\text { across the region. }\end{array}$ \\
\hline $\begin{array}{l}\text { Sustainable Energy } \\
\text { Fund for Africa }\end{array}$ & $\begin{array}{l}\text { The project supports small- and medium-scale renewable energy and energy } \\
\text { efficient projects in Africa. }\end{array}$ \\
\hline $\begin{array}{l}\text { Africa-EU Renewable } \\
\text { Energy Cooperation } \\
\text { Programme (RECP) }\end{array}$ & $\begin{array}{l}\text { The programme's goal is to increase renewable energy use and access to modern } \\
\text { energy for about } 100 \text { million people by } 2020 \text {. It also supports Africa with policy } \\
\text { advice, private sector co-operation, project preparation support activities, and } \\
\text { capacity development. }\end{array}$ \\
\hline $\begin{array}{l}\text { African Renewable } \\
\text { Energy Fund (AREF) }\end{array}$ & $\begin{array}{l}\text { This is a private equity fund investing in small- and medium-scale renewable energy } \\
\text { projects in Africa. It also assists governments to meet their renewable energy and } \\
\text { carbon emission targets. }\end{array}$ \\
\hline $\begin{array}{l}\text { Capital Access for } \\
\text { Renewable Energy } \\
\text { Enterprises } \\
\text { Programme (CARE2) }\end{array}$ & $\begin{array}{l}\text { This is another financing programme that aims to expand renewable energy } \\
\text { markets in selected African countries by augmenting capital to businesses. It is } \\
\text { supported by the Swedish International Development Cooperation Agency. }\end{array}$ \\
\hline $\begin{array}{l}\text { ACP-EU Energy } \\
\text { Facility }\end{array}$ & $\begin{array}{l}\text { This is a co-financing instrument to extend sustainable energy access in } \\
\text { impoverished rural communities in Africa. }\end{array}$ \\
\hline $\begin{array}{l}\text { Sustainable Energy } \\
\text { Fund for Africa } \\
\text { (SEFA) }\end{array}$ & $\begin{array}{l}\text { A Danish Government commitment administered by the African Development Bank } \\
\text { to support small-and medium-scale clean energy and energy efficiency projects in } \\
\text { Africa through grants for technical assistance and capacity-building, investment } \\
\text { capital, and guidance. }\end{array}$ \\
\hline
\end{tabular}

\subsection{Maturing niche renewable technologies}

The pattern of the development of a new technology from inception to extinction differs, depending on various factors affecting it at different stages of its lifespan. These factors include the unique consumer need it serves, the cost involved, the relative benefit of consuming an alternative/ substitute, and the satisfaction it provides relative to other prevailing technologies [31]. These factors not only determine how quickly the technology is accepted among consumers, but also how long it remains relevant to them. New technology is more likely to scale up faster if it offers better performance and efficiency and is more affordable than the incumbent technology. Late adopters can transition easily and faster to such novel technology due to the experiences of early adopters and the declining cost based on technology improvement [82]. The rapid adoption of mobile phones in Africa is an embodiment of the rapid transition route for late adopters. Developing countries in sub-Saharan African can replicate this fast transition experienced in mobile telecommunication within their energy and electricity generation sectors through renewables, as niches gain growth momentum. Fast transition for late adopters is observed across industries, for instance in the transport sector literature [31] and the supply end-use technologies sector [83]. In a market where there is an existing niche segment (as is the case with renewables in sub-Saharan Africa), it could 
offer new technologies the opportunity to test their viability. Another reason to scale up new technology is comparative advantage [82]. The global sustainability concern and the investment initiatives from international agencies encourage the advancement of niche energy technologies in developing countries. Kenya, for example, is one of the top five countries globally to have increased geothermal power significantly in 2013 [59]. The growing niche technologies in sub-Saharan Africa are an indication that the region is poised to leapfrog the present fossil energy regime.

\subsection{Weakening renewable energy cost hypothesis}

It is widely argued that renewables are more costly than fossil energy, without factoring in the weight of subsidies, context, and technology specifics. To demonstrate an appropriate cost comparison of different energy options, it is important to understand how much households without access to electricity presently spend on accessing their main energy services. These include lighting, cooking and water heating, space heating, cooling, communications, and earning a living [2]. It is also essential that a cost comparison of fossil fuel and renewable energy is not simply assessed on the basis of production unit cost, but that it investigates overall cost elements - the levelised cost of electricity (LCOE). In fact, a recent sensitivity analysis conducted by Carbon-Tracker [17] using the LCOE metric suggests that the global average costs of renewable power are presently lower than those of power generated from fossil fuels, and predicts even more cost-resilient renewable energy plants by 2020. Without factoring in the health benefits, energy security cost, environmental cost, and other opportunity costs, Error! Reference source not found. shows the consistent decline in the cost of solar photovoltaics since 1977, as an example.

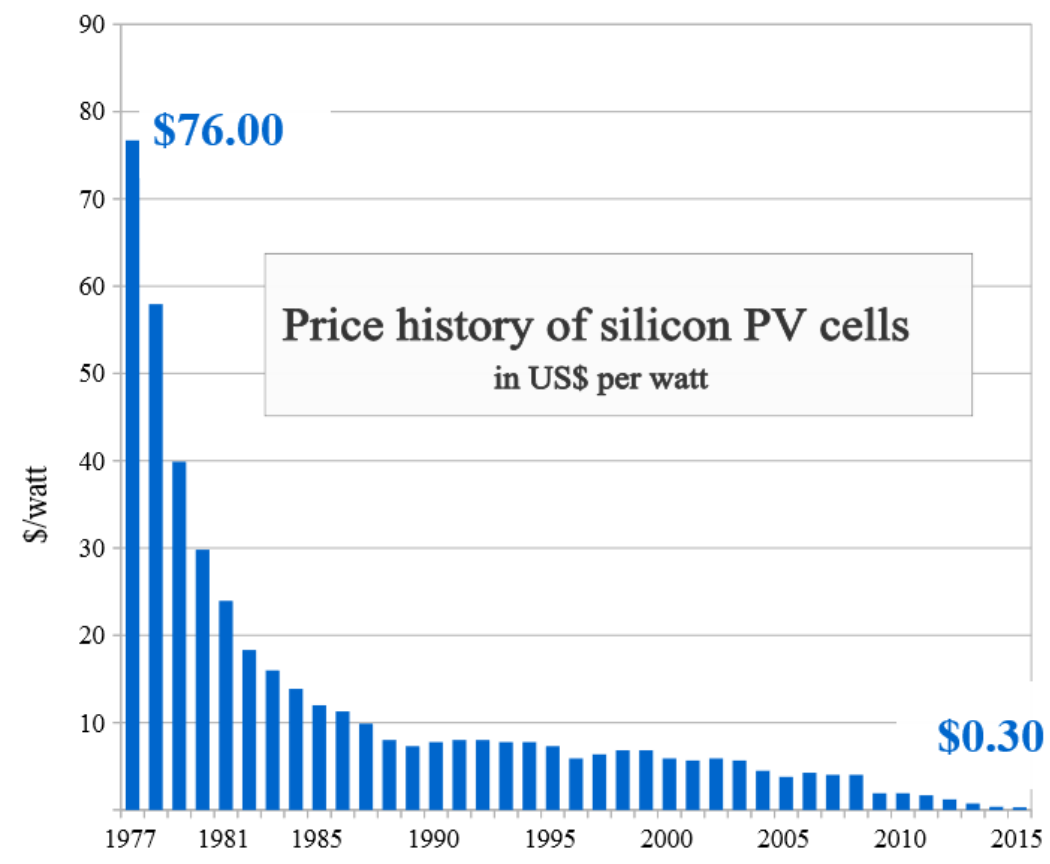

Figure 4: Solar PV power cost from 1977 to 2015 (Source: Bloomberg-New-Energy-Finance [15])

The transmission of electricity from a national grid source to a remote and low-density population settlement might not be justifiable when compared with stand-alone or mini-grid renewable energy. According to Szabo, Bódis, Huld, \& Moner-Girona [71], for the greater proportion of rural dwellers who live within 100 kilometres of an existing grid system, solar PV could still prove an economically feasible option than grid extension. In their study of two electricity deficit countries - Nigeria and Ethiopia - Nerini, Broad, Mentis, Welsch, Bazilian, \& Howells [53] concluded that stand-alone and minigrid systems are found to be cost-effective in providing electricity access to the least-populated remote areas. In order to expound adequately on the cost of renewable energy technologies in relation to fossil fuels, it is important critically to assess and analyse the opportunity cost of living without electricity at all due to an inaccessible power supply from the national grid or from fossil energy sources, versus accessing electricity from the presently 'expensive' renewables, the cost of 
which is continuously declining. Though the argument that renewable energy is expensive and hence possesses little incentive for investors exists, it has little or no support when assessed in the context of a market that currently has no electricity and where renewable energy opportunities prevail. It is even less cogent when one considers the improvement in the quality of life, education, economic opportunities, and usability of modern technologies (e.g., computers instead of typewriters) that is largely driven by access to electricity. The correlation between electricity access and real per capita GDP [4], economic development [23], and the human development index [81] heightens the relevance of electricity access today. It appears, therefore, that to live without electricity access would cost more than electricity accessed through 'costly' renewable sources, as the benefits accrued through access would be forfeited. Despite the emphasis on the distinguishing cost differences and limitations of renewables in relation to fossil energy (which has been the focus of some recent studies such as those of Stram [70]), when accessed on the basis of opportunity cost, electricity via renewable energy is justified.

\subsection{Growing population and urbanisation}

The global population is expected to almost double by the end of this century [80]. Keho [42] identifies the combination of population growth and urbanisation as one of the key drivers of energy consumption. Given its relatively higher population growth compared that that of developed countries, sub-Saharan Africa is set to record significant increases in energy and electricity demand. The number of people who would still be without electricity by 2030 , under a 'business as usual' scenario, is projected by scholars to be either 600 million [61] or 822 million [55]. This additional population without access to electricity, coupled with presently limited fossil energy resources, makes the need for the rapid integration of renewable energy in the total energy mix is compelling. Pessimists about renewable energy usually question the efficacy of renewables as a substitute for the present fossil regime on the basis of cost and capacity factors. With ever-expanding cities and increasing technological reach around the world, the execution of basic services increasingly depends on energy. A growing number of consumer appliances and devices are powered by electricity. To satisfy this increasing need for energy, exploration for and the adoption of renewable energy technologies is becoming less of a choice and more of an obligation in order to meet basic societal needs.

\section{$5 \quad$ RECONCEPTUALISING LEAPFROGGING PARADIGMS}

A conceptual leapfrogging framework, based on the types and potential leapfrogging drivers, is introduced. The framework captures how a typical case of leapfrogging would emerge, depending on the extent to which such potential drivers of leapfrogging are present in the given context. Contextualising a framework for leapfrogging in emerging economies, Binz, Truffer, Li, Shi, \& Lu [14] observe that there is a need to assess the performance of technological innovation systems based on three main categories. These are: the context of the industrialising country; the scale of international innovation capacity beyond the contextual scope; and the interplay between the global and contextual dimensions of technological innovation systems. They also highlight the role of other entities such as universities, research institutes, and other organisations or actors that might influence the effect of global technological innovation systems on local innovation. Binz et al. [14] also identified six leapfrogging pathways: international competition, global innovation, foreign direct investments, isolated regime formation, export oriented leapfrogging, and low leapfrogging potential. These leapfrogging trajectories, unlike the three types of leapfrogging illustrated in Error! Reference source not found., outline how innovation develops depending on its point of origin and scope of reach. This categorisation highlights the combination of factors that determine the advancement of a new technology innovation, but does not necessarily describe what leapfrogging entails.

Although the concept of leapfrogging involves a form of change fuelled by innovation, most leapfrogging concepts focus mainly on technological innovation [25, 46, 52, 65, 72]. Technological innovation is a precursor to leapfrogging, but is not the sole determinant. Leapfrogging requires more than the development of a new technology [52]. This implies that the social aspects of change are relevant and should be considered in order to achieve success in leapfrogging. Society also needs to recognise an added value in the new innovation, relative to the prevailing alternatives [73]. Transition management is therefore crucial for introducing niche technologies into a market of regime technologies, or in one lacking them. Innovation and niche development need to be linked with the social context for which they are intended, especially when there is a supply push technology. This paper conceptualises two major dynamics essential for characterising leapfrogging 
trajectories in electricity markets. These are pace and magnitude, where pace is defined as either fast or slow, and magnitude as either large or small. A combination of these descriptions illustrates three paradigms of leapfrogging: revolutionary, coned, and scattered, with a fourth paradigm, conventional transition. These are illustrated in Error! Reference source not found..

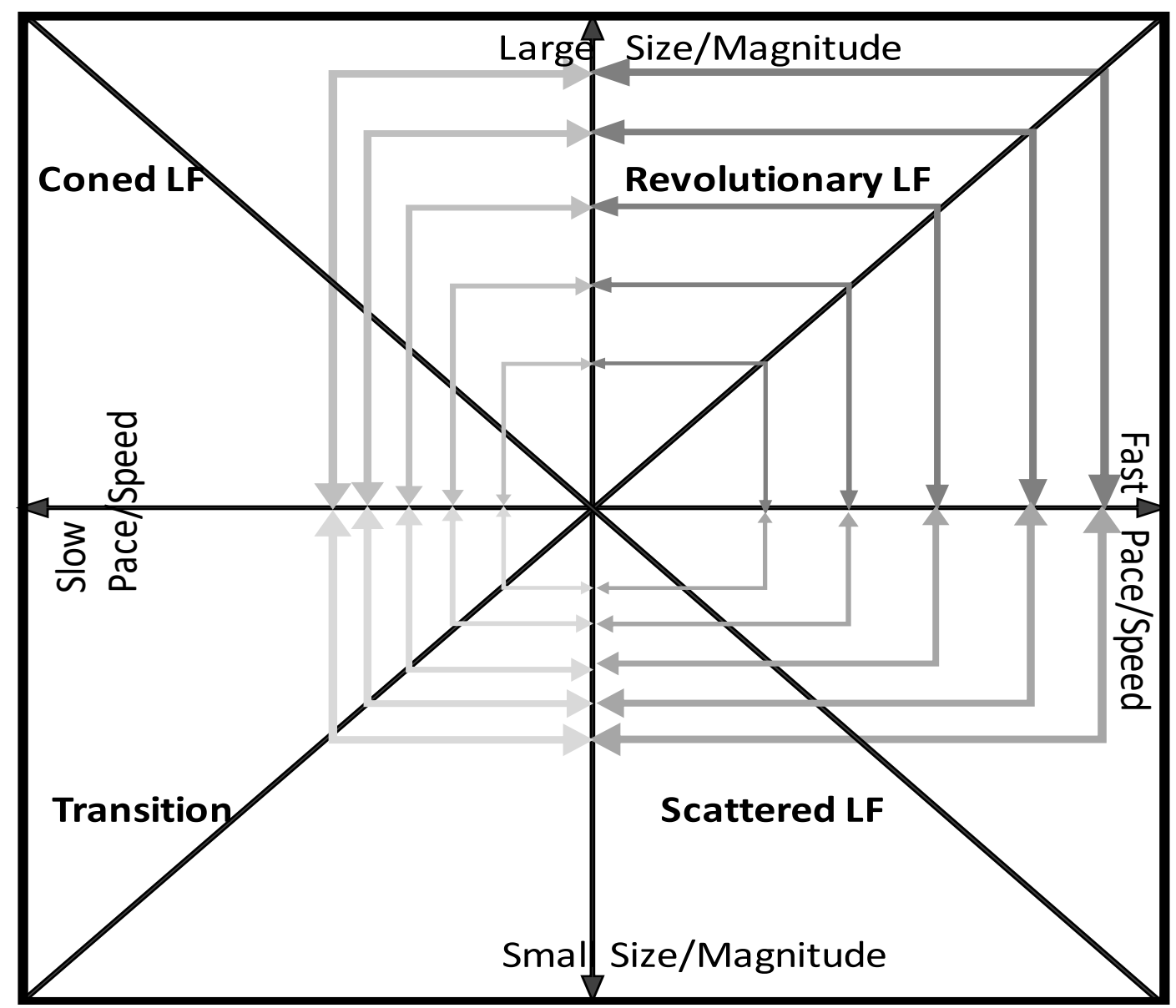

Figure 5: Conceptualised leapfrogging trajectories (Source: Authors)

\subsection{Revolutionary leapfrogging}

Revolutionary (strong) leapfrogging refers to a situation where the transition from one technology, and the adoption of a novel one, happens quickly and on a large scale due to the characteristics of the new technology compared with the current technology, as well as the capabilities of the adopter. For example, transitioning from traditional energy (such as biomass) to modern and clean energy (such as renewable energy) can happen on a large scale if the context/market under consideration (1) is without large-scale infrastructure of conventional energy, (2) has unmet demand for energy, and (3) is characterised by affordable cost and availability of renewable energy [22] and the unreliable capacity of the existing infrastructure. These features imply that transition in the described context can occur at a faster pace and on a larger scale. This form of transition is referred to in this paper as revolutionary leapfrogging. A relevant example is Kuwait's discovery of oil, which led to a quick transition within a five-year period (1945-1949) and within which the mode of transport changed from camels and donkeys to modern motor vehicles [7]. In revolutionary leapfrogging, there is a greater tendency to witness an abundance of resources and a highly innovative adopter.

\subsection{Scattered leapfrogging}

Scattered (medium) leapfrogging is a transition with some characteristics of revolutionary leapfrogging, except that the magnitude of change is small. This could be as a result of an existing large-scale infrastructure that takes time to be decommissioned. There is no shortage of resources 
for building new infrastructure, but the availability/full capacity of the current infrastructure diminishes the need for the creation of a new one on a large scale. Small additions of the new latest technology will be experienced, but at a faster rate. This form of leapfrogging is described in this paper as scattered, as it involves fast-paced creation of small and distributed new technology. An example can be found in Canada, where the state of Ontario transitioned from coal for electricity production to a cluster of renewables (solar, nuclear, and hydroelectricity) between 2003 and 2014. This eventually led to the shutdown of about 7,573 MW of coal capacity. A similar situation happened in The Netherlands and France, where natural gas for electricity production rose from two per cent in 1959 to 50 per cent in 1971, and nuclear grew from four per cent in 1974 to 40 per cent in 1982 [68].

\subsection{Coned leapfrogging}

Coned (weak) leapfrogging is a form of transition that involves movement from existing sociotechnical systems to a novel one. Given the existing large-scale infrastructure that needs to be changed, the amount of change is large, and hence occurs at a slower pace. This is a weak form of leapfrogging, since the adoption of the new technology occurs over a longer period of time. A good example would be Denmark, which leapfrogged its electricity production to 95 per cent coal-based from 90 per cent oil-based [68] within a period of nine years (1976-1985).

\subsection{Conventional transition}

Conventional transition is a form of transition that occurs when a variety of natural influences cause humanity to adjust and adapt. Given that major natural transition takes decades to occur, conventional transition is very slow, with small changes that occur over time. The seemingly small nature of their occurrence may seem insignificant, but the accumulated effect may be large. Conventional transition is not regarded as leapfrogging, as it does not involve a skip in pace or magnitude during the transition process.

The features of the leapfrogging paradigms are summarised in Error! Reference source not found..

Table 2: Characteristics of leapfrogging trajectories

\begin{tabular}{|c|c|c|c|}
\hline & \multicolumn{3}{|c|}{ Pace } \\
\hline & & Fast & Slow \\
\hline \multirow{2}{*}{ 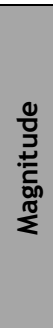 } & Large & $\begin{array}{l}\text { Revolutionary (strong) leapfrogging } \\
\text { - Small-scale current infrastructure } \\
\text { - Unreliable current infrastructure } \\
\text { - Unmet market needs } \\
\text { - Available and affordable alternatives }\end{array}$ & $\begin{array}{l}\text { Coned (weak) leapfrogging } \\
\text { - Large-scale current infrastructure } \\
\text { - Declining current infrastructure } \\
\text { - Limited and expensive alternatives }\end{array}$ \\
\hline & Small & $\begin{array}{l}\text { Scattered (medium) leapfrogging } \\
\text { - Large-scale current infrastructure } \\
\text { - Fully satisfied market } \\
\text { - Available and affordable alternatives }\end{array}$ & $\begin{array}{l}\text { Transitional (conventional) leapfrogging } \\
\text { - Large-scale current infrastructure } \\
\text { - Reliable current infrastructure } \\
\text { - Fully satisfied market } \\
\text { - Less affordable alternatives }\end{array}$ \\
\hline
\end{tabular}

The conceptualisation of leapfrogging presented in Error! Reference source not found. suggests that some essential elements, such as the size and performance of the existing market infrastructure and the unmet market demand, can steer a transition that would otherwise require a longer period of time towards adopting a revolutionary leapfrogging paradigm. Some of these essential elements for leapfrogging are evident in the literature [47, 67, 72]. Critical to the success of leapfrogging is the availability of new technology/resources to provide an improved service bundle.

\section{CONCLUSION}

It is apparent that an over-reliance on conventional energy would hinder the attainment of the seventh sustainable development goals (SDG7) - that is, universal access to modern energy. Against this backdrop, this paper has examined the potential of, and opportunity for, leapfrogging to renewable energy in unmet electricity markets in sub-Saharan Africa - a region characterised by a relatively small energy infrastructure that is accentuated by the size of its unmet electricity markets. The region, therefore, does not need to 'burden' itself with 'dirty' fossil energy in order to attain universal access to electricity. This paper has identified, among other things, the pursuit of SDGs, the financial/capital inflow from development partners, the abundance of renewable energy resources, the declining cost of renewable technology, the continuous improvement in 
technology efficiency, and the growing demand for electricity propelled by the growing population and increasing urbanisation, as the potential key drivers of sub-Saharan Africa's readiness to leapfrog to renewable energy as a reliable alternative to fossil fuels for a secure and sustainable energy future.

Having identified the key features illuminating the path of renewable energy leapfrogging in unmet electricity markets, the trajectory of leapfrogging that can be observed is reconceptualised in three paradigms: revolutionary, coned, and scattered. These paradigms are based on the combination of the pace and magnitude of change in a given transition setting. The pace and magnitude of change also depends on the level of existence of the potential leapfrogging drivers discussed. Specific countries in the sub-region, for example, may have greater financial strength, enabling them to undertake large-scale renewable infrastructure development at a slower pace. Others, more endowed with distributed renewable energy resources, would find it ideal to build small-scale infrastructure at a faster pace. This means that different pathways to energy technology development, adoption, and absorption would eventually emerge. Generally, the sub-Saharan African electricity market is well-suited to the three leapfrogging paradigms.

Although there are vast opportunities for sub-Saharan Africa's unmet electricity market to leapfrog to renewable energy, predictable obstacles remain that ought to be addressed to ensure an efficient transition environment. In socio-technical systems such as energy, the challenges to leapfrogging can be multi-faceted. They not only require market preparedness in order to adopt new technology, but also the innovative readiness to provide the required technology. Some notable challenges include: an awareness of the political environment in order to stimulate its readiness and receptivity towards renewable energy as the way forward; an internal financial commitment to undertake renewable energy investment beyond what is received in aid and donations from development partners; technical training to improve renewable energy innovation; technology cost and efficiency; liberalisation of the energy market to attract private sector participation; and strategic policy finetuning that commits to renewable energy objectives and targets. It is imperative that renewable energy leapfrogging in sub-Saharan Africa be pursued with a consciousness of these potential challenges. For a start, market liberalisation - specifically, deregulating electricity production and incentivising active private sector participants in the energy sector - would encourage competitiveness and thus contribute to expediting access to electricity. This would also alleviate the excessive capital burden on governments and public institutions as they endeavour to provide adequate energy. Ironically, the intensity of these challenges is mitigated by the gravity of the problem (large 'awaiting' demand market). There is a significant payoff for those leapfrogging through path-skipping and path-creating, as it is for early market entrants or technology adopters. The penalty for path-following leapfrogging is the difficult choice of abandoning old technological infrastructures before they exhaust their useful lifespan, or of remaining stuck in obsolescence. The former can be observed in telecommunication, where late adopters of landline/wired modes underused such infrastructures following the emergence and rapid diffusion of mobile phones.

This paper attests to the need for energy transition in sub-Saharan Africa, and the urgent need to expedite the integration of renewable energy in the overall energy mix. Opportunely, the global interest in energy sustainability and environmental safety has awoken the energy sector to opportunities in renewable energy, where new electricity systems can be built on the foundation of renewable energy flows instead of the present fossil energy stocks. Global stakeholders, not just those in the continental market, are actively participating in the search for a quick solution to the energy problem in unmet electricity markets such as Africa. These opportunities serve as a springboard to leapfrog unmet electricity markets to a new era where electricity would be accessed largely through renewable sources, and thus contribute towards avoiding the adverse climatic consequences of the current high dependency on fossil fuel.

\section{REFERENCES}

[1] Abdul-Salam, Y. \& Phimister, E. 2016. The politico-economics of electricity planning in developing countries: A case study of Ghana. Energy Policy, 88, pp. 299-309.

[2] Action, P. 2010. Poor people's energy outlook 2010. Rugby, UK.

[3] Asian Development Bank (ADB). 2010. Guidelines for estimating Asian Development Bank (ADB) investments in access to energy projects. /http://www.asiandevbank.org/Documents/Clean-Energy/efabrief.pdfS. Accessed on 24 May 2016. 
[4] Adom, P.K. 2011. Electricity consumption-economic growth nexus: The Ghanaian case. International Journal of Energy Economics and Policy, 1, p. 18.

[5] Africa-Progress-Panel. 2015. Africa Progress Report "Power People Planet: Seizing Africa's energy and climate opportunities". Africa Progress Panel.

[6] AGECC U. 2010. Energy for a sustainable future: Summary report and recommendations. UN (United Nations)/The Secretary-General's Advisory Group on Energy and Climate Change. New York, USA.

[7] Al-Marafie, A. 1989. Assessment of oil and natural gas resources in Kuwait. Energy, 14, pp. 1-7.

[8] Amankwah-Amoah, J. 2015. Solar energy in sub-Saharan Africa: The challenges and opportunities of technological leapfrogging. Thunderbird International Business Review, 57, pp. 15-31.

[9] Andersen, T.B. \& Dalgaard, C.-J. 2013. Power outages and economic growth in Africa. Energy Economics, 38, pp. 19-23.

[10] Asami, M. \& Nawfal, S. 2015. Africa power sector: Planning and prospects for renewable energy. IRENA SYNTHESIS REPORT.

[11] Bastakoti, B.P. 2003. Rural electrification and efforts to create enterprises for the effective use of power. Applied Energy, 76, pp. 145-55.

[12] Batinge, B., Musango, J.K. \& Alan, C.B. Forthcoming. Sustainable energy transition framework for unmet electricity markets.

[13] Bhattacharyya, S.C. \& Palit, D. 2016. Mini-grid based off-grid electrification to enhance electricity access in developing countries: What policies may be required? Energy Policy, 94, pp. 166-78.

[14] Binz, C., Truffer, B., Li, L., Shi, Y. \& Lu, Y. 2012. Conceptualizing leapfrogging with spatially coupled innovation systems: The case of onsite wastewater treatment in China. Technological Forecasting and Social Change, 79, pp. 155-71.

[15] Bloomberg-New-Energy-Finance. 2016. New Energy Outlook 2016. https://aboutbnefcom/.

[16] Burlamaqui, L. \& Kattel, R. 2016. Development as leapfrogging, not convergence, not catch-up: Towards Schumpeterian theories of finance and development. Review of Political Economy, 1, p. 19.

[17] Carbon-Tracker. 2016. End of the load for coal and gas? http://wwwcarbontrackerorg/wpcontent/uploads/2016/09/End-of-the-load-for-coal-and-gas_Exec-Summary_web-6pdf. Accessed on September 192016.

[18] Carlsson, B. 2003. Innovation systems: A survey of the literature from a Schumpeterian perspective. Paper for the Elgar Companion to Neo-Schumpeterian Economics, June.

[19] Castellano, A., Kendall, A., Nikomarov, M. \& Swemmer, T. 2015. Brighter Africa: The growth potential of the sub-Saharan electricity sector. Johannesburg: McKinsey and Company.

[20] Corrêa da Silva, R., de Marchi Neto, I. \& Silva Seifert, S. 2016. Electricity supply security and the future role of renewable energy sources in Brazil. Renewable and Sustainable Energy Reviews, 59, pp. 328-41.

[21] Eberhard, A., Foster, V., Briceño-Garmendia, C., Ouedraogo, F., Camos, D. \& Shkaratan, M. 2008. Underpowered: The state of the power sector in Sub-Saharan Africa. Background Paper, p. 6.

[22] EC SA, UN. 2012. Sustainable energy for all: Action plan. UN Report.

[23] Eshun, M.E. \& Amoako-Tuffour, J. 2016. A review of the trends in Ghana's power sector. Energy, Sustainability and Society, 6, pp. 1-9.

[24] Fouquet, R. 2010. The slow search for solutions: Lessons from historical energy transitions by sector and service. Energy Policy, 38, pp. 6586-96.

[25] Gallagher, K.S. 2006. Limits to leapfrogging in energy technologies? Evidence from the Chinese automobile industry. Energy Policy, 34, pp. 383-94.

[26] García-Gusano, D., Iribarren, D., Martín-Gamboa, M., Dufour, J., Espegren, K. \& Lind, A. 2016. Integration of life-cycle indicators into energy optimisation models: The case study of power generation in Norway. Journal of Cleaner Production, 112, pp. 2693-6.

[27] Geels, F.W. 2002. Technological transitions as evolutionary reconfiguration processes: A multi-level perspective and a case-study. Research Policy, 31, pp. 1257-74.

[28] Gnansounou, E., Bayem, H., Bednyagin, D. \& Dong, J. 2007. Strategies for regional integration of electricity supply in West Africa. Energy Policy, 35, pp. 4142-53.

[29] Goldemberg, J. 1998. Leapfrog energy technologies. Energy Policy, 26, pp. 729-41.

[30] Goldemberg, J. 2011. Technological leapfrogging in the developing world. Georgetown Journal of International Affairs, 12, pp. 135-41.

[31] Grubler, A. 2012. Energy transitions research: Insights and cautionary tales. Energy Policy, 50, pp. 8-16.

[32 GSMA. 2015. State of the industry report - Mobile money. http://wwwgsmacom/ mobilefordevelopment/wp-content/uploads/2016/04/SOTIR_2015pdf.

[33] Hobday, M. 1995. Innovation in East Asia. Edward Elgar Publishing.

[34] ICSU, ISSC. 2015. Review of targets for the sustainable development goals: The science perspective. ICSU, ISSC, http://www. icsu. org/publications/reports-and-reviews/review-of-targets-for-the-sustainabledevelopment-goals-the-science-perspective-2015/SDG-Report. pdf.

[35] IEA. 2009. Cities, towns \& renewable energy: Yes in my front yard. International Energy Agency.

[36] IEA. 2014. Energy Policies of IEA Countries. OECD/IEA, Paris, France.

[37] IEA. 2014. The power of transformation: Wind, sun and the economics of flexible power systems. http: / /www.iea.org.

[38] IEA. 2015. Key world statistics 2015.

[39] IEA. 2015. World energy outlook. Methodology for Energy Access Analysis. OECD/IEA, Paris, France.

[40] IEA. 2015. World energy outlook. OECD/IEA, Paris, France.

[41] IEA. 2015. World energy outlook 2015: Special report on energy and climate change. http: //www.iea.org. 
[42] Keho, Y. 2016. What drives energy consumption in developing countries? The experience of selected African countries. Energy Policy, 91, pp. 233-46.

[43] Kemp, R., Rotmans, J. \& Loorbach, D. 2007. Assessing the Dutch energy transition policy: How does it deal with dilemmas of managing transitions? Journal of Environmental Policy \& Planning, 9, pp. 315-31.

[44] Kitzing, L., Katz, J., Schröder, S.T., Morthorst, P.E. \& Møller Andersen, F. 2016. The residential electricity sector in Denmark: A description of current conditions. Technical University of Denmark: Lyngby, Denmark

[45] KPMG. 2015. Power in Africa. Sector report. Kpmg.com/africa. Accessed on August 17, 2016.

[46] Lee, K. \& Lim, C. 2001. Technological regimes, catching-up and leapfrogging: Findings from the Korean industries. Research Policy, 30, pp. 459-83.

[47] Levin, T. \& Thomas, V.M. 2016. Can developing countries leapfrog the centralized electrification paradigm? Energy for Sustainable Development, 31, pp. 97-107.

[48] Mendoza, N.B. 2016. 6 initiatives tackling African electrification <devex.com-6 initiatives tackling African electrification.pdf>.

[49] Mody, A. \& Sherman, R. 1990. Leapfrogging in switching systems. Technological Forecasting and Social Change, 37, pp. 77-83.

[50] Morris, C. \& Pehnt, M. 2012. Energy transition: The German energiewende. Heinrich Böll Stiftung. https: / /book.energytransition.org/sites/default/files/downloads-2016/book/German-EnergyTransition_en.pdf Accessed on August 20, 2016.

[51] Mu, Q. \& Lee, K. 2005. Knowledge diffusion, market segmentation and technological catch-up: The case of the telecommunication industry in China. Research Policy, 34, pp. 759-83.

[52] Murphy, J.T. 2001. Making the energy transition in rural East Africa: Is leapfrogging an alternative? Technological Forecasting and Social Change, 68, p. 173-193.

[53] Nerini, F.F., Broad, O., Mentis, D., Welsch, M., Bazilian, M. \& Howells, M. 2016. A cost comparison of technology approaches for improving access to electricity services. Energy, 95, pp. 255-65.

[54] Pachauri, S., Rao, N., Nagai, Y. \& Riahi, K. 2012. Access to modern energy: Assessment and outlook for developing and emerging regions. IIASA, Laxenburg, Austria.

[55] Panos, E., Densing, M. \& Volkart, K. 2016. Access to electricity in the World Energy Council's global energy scenarios: An outlook for developing regions until 2030. Energy Strategy Reviews, 9, pp. 28-49.

[56] Perez, C. 1988. "New Technologies and Development”. In Small Countries Facing the Technological Revolution, Edited by: Freeman, C. and Lundvall, B-A. London: Pinter. Ch.4. Frances Pinter Publishers Ltd.

[57] Perkins, R. 2003. Environmental leapfrogging in developing countries: A critical assessment and reconstruction. Natural Resource Forum, 27, pp. 177-88.

[58] REN21. 2014. Renewables 2014 - Global status report. REN21. Paris: Tech Rep.

[59] Schroeder, P.M., Chapman, R.B. 2014. Renewable energy leapfrogging in China's urban development? Current status and outlook. Sustainable Cities and Society, 11, pp. 31-9.

[60] Scott, A. 2015. Building electricity supplies in Africa for growth and universal access. Background paper for Power. People, Planet: Seizing Africa's energy and climate opportunities.

[61] SE4All. 2012. A framework for action. http://wWw.se4all.org/sites/default/files/l/2013/ 09/SE_for_All_Framework_for_Action_FINAL.pdf.

[62] Shyu, C.-W. 2014. Ensuring access to electricity and minimum basic electricity needs as a goal for the post-MDG development agenda after 2015. Energy for Sustainable Development, 19, pp. 29-38.

[63] Smil, V. 2010. Energy transitions: History, requirements, prospects: ABC-CLIO.

[64] Soete, L. 1985. International diffusion of technology, industrial development and technological leapfrogging. World Development, 13, pp. 409-22.

[65] Sovacool, B.K. 2013. Energy \& ethics: Justice and the global energy challenge. : Springer. Palgrave Macmillan.

[66] Sovacool, B.K. 2016. Differing cultures of energy security: An international comparison of public perceptions. Renewable and Sustainable Energy Reviews, 55, pp. 811-22.

[67] Sovacool, B.K. 2016. How long will it take? Conceptualizing the temporal dynamics of energy transitions. Energy Research \& Social Science, 13, pp. 202-15.

[68] Steinbuks, J. \& Foster, V. 2010. When do firms generate? Evidence on in-house electricity supply in Africa. Energy Economics, 32, pp. 505-14.

[69] Stram, B.N. 2016. Key challenges to expanding renewable energy. Energy Policy. 96, pp.728-734

[70] Szabo, S., Bódis, K., Huld, T. \& Moner-Girona, M. 2011. Energy solutions in rural Africa: Mapping electrification costs of distributed solar and diesel generation versus grid extension. Environmental Research Letters, 6, p. 034002.

[71] Szabó, S., Bódis, K., Huld, T. \& Moner-Girona, M. 2013. Sustainable energy planning: Leapfrogging the energy poverty gap in Africa. Renewable and Sustainable Energy Reviews, 28, pp. 500-9.

[72] Tigabu, A.D., Berkhout, F. \& van Beukering, P. 2015. The diffusion of a renewable energy technology and innovation system functioning: Comparing bio-digestion in Kenya and Rwanda. Technological Forecasting and Social Change, 90, pp. 331-45.

[73] Tukker, A. 2005. Leapfrogging into the future: Developing for sustainability. International Journal of Innovation and Sustainable Development, 1, pp. 65-84.

[74] UN. 1992. United Nations framework convention on climate change.

[75] UN. 1998. Kyoto Protocol to the United Nations framework convention on climate change. Kyoto Protocol, Kyoto, 19.

[76] UN. 2011. Framework Convention on Climate Change. Cancun, Mexico.

[77] UN. 2015. Conference of the parties. Framework convention on climate change. Paris, France. 
[78] UN. 2015. Transforming our world: The 2030 agenda for sustainable development. http://www.un.org/ga/search/view_doc.asp?symbol=A/RES/70/1\&Lang=E.

[79] UN United Nations, Department of Economic and Social Affairs, Population Division (2015). World Population Prospects: The 2015 Revision, Key Findings and Advance Tables. Working Paper No. ESA/P/WP.241.

[80] UNDP. 2015. Human development report 2015. New York, NY, USA. http://hdr.undp.org. Accessed on September 132016.

[81] WHO. 2014. Burden of disease from household air pollution for 2012. Geneva: World Health Organization (WHO).

[82] Wilson C. 2009. Meta-analysis of unit and industry level scaling dynamics in energy technologies and climate change mitigation scenarios. IIASA Interim Report. http://pure.iiasa.ac.at/9120/. Accessed on May 232016.

[83] Wilson C. 2012. Up-scaling, formative phases, and learning in the historical diffusion of energy technologies. Energy Policy, 50, pp. 81-94.

[84] Zerriffi, H. \& Wilson, E. 2010. Leapfrogging over development? Promoting rural renewables for climate change mitigation. Energy Policy, 38, pp. 1689-700. 